\title{
Discussion on the Work of College Network Ideological and Political Education
}

\author{
Xianfa Lan \\ NanChang Institute of Science \& Technology, Jiangxi Nanchang, 330108
}

\begin{abstract}
Keywords: Colleges; Network ideological and political education; Problems and current situation; Countermeasures
\end{abstract}

\begin{abstract}
Since the popularization of colleges digitization, the traditional ideological and political education can not meet the needs of college students. It is urgent to carry out ideological and political education with the times by the means of computer network. It is necessary and urgent to carry out the network ideological and political education in colleges, whether it is from the perspective of improving the quality of education or from the perspective of adapting to the way of learning. This paper focuses on the outstanding problems on the network of ideological and political education in colleges, and on the basis of fully understanding and analyzing the problems, put forward how to strengthen the network ideological and political education team construction, construct the teaching methods of adapting to the network ideological and political education interaction and service, improving the available policy for the network ideological and political education resources, providing more scientific and standardized implementation of the theoretical reference for the future of the network of ideological and political education.
\end{abstract}

\section{Introduction}

With the rapid development of computer network technology in the information age, the network information technology has been popularized rapidly in our country. As "the modern generation residents" modern students in the information age, computers and networks have penetrated into all aspects of their life and study, followed the development of wireless networks, the popularity of personal network terminal equipment and the rapid rise of mobile networks, making the network tool more widely concerned about and used by college students, it is no exaggeration to say that the network has become a necessity for their lives. In foreign countries, remote network education, MOOC classroom has long been nothing new, university classroom notebook computers and wireless networks have become standard sets. Although China's higher education has a certain gap in terms of hardware and software when compared with the developed countries, the current popularity of the speed of information technology, computer networks, mobile internet and other school education have become an irresistible development trend.

As an important part of China's higher education, the ideological and political education of college students, actively exploring and opening up the way of network education, not only beneficial to for the basic ideological and political education and daily education, but also greatly promote the function on how to cultivate a healthy personality in the network era. Therefore, establishing the network ideological and political education system in line with China's national conditions and constantly improving the network ideological and political education methods and means, is the task of ideological and political education in this era, also is inevitable development trend of ideological and political education in the future .

\section{The Revolutionary Breakthrough in Communication Technology of Educational Content}

The popularization of information network technology has broken the limitation of time and space of information exchange, greatly changed the way of social information communication, and profoundly influenced the environment of ideological and political education. The Internet covers every corner of the world, and convey information between countries at the speed of light, greatly 
shortening the distance between the individual information exchange, the world has become a veritable "global village". The information in the Internet is digital information, that is, the information waiting for being shared and transmitted are organized in the form of digitization, and turned into electronic signals, spreading between the various terminals by the network. The speed of network information dissemination is the embodiment of time compression, the breakthrough of the country boundary means that the space and distance are much closer.

In the information society, the first time to obtain information not only determines the level of economic efficiency, but also determines whether the country can occupy the ideological high ground, so the spread of information breaking the boundaries and space have an important significance on political, economic and social development. Ideological and political education work expanded by Network technology provide a convenient condition for the timely propaganda of the party's ideological line, political program, policies and regulations and other socialist ideology, the consolidation of socialist ideological and cultural positions. The huge amount of information from network not only provides rich resources for ideological and political education, but also hides the political nature of educational content, improves the cultural connotation of educational content and the technical level of educational means.

The network makes the subject and object of ideological and political education more targeted and more easily to get required ideological and political education information from the network, so as to get rid of a large number of newspapers and books to find the dilemma of information. Ideological and political education software, red website, revolutionary film, online teaching, online exhibition, online lectures and others can become the carrier of ideological and political education, ideological and political education information can also be updated through the network, so that educators can promptly obtain the latest information of education, to greatly improve the timeliness of ideological and political education.

\section{Problems and Current Situation of Network Ideological Education in Colleges}

The Weakening of Educational-Oriented Function. Due to the characteristics of the information communication on the Internet, information management and public opinion control are unprecedentedly increased, the first is that the Internet information are complicated, but for the management and monitoring staff, their time and energy is limited, it is difficult to do the authenticity of all the information one by one; The second is that the definition of private space and public space is vague, especially in the network, so management and control personnel is difficult to develop the scope of the review and the use of specific methods; The third is the Internet as a new media, has a significant difference with traditional media, the traditional media review system and methods can not be copied to the network field.

The popularity of the network has reduced the authority of the educator, before the emergence of the network, information asymmetry in the process of ideological and political education, educators hold the main information, information advantage determines the educator dominate the whole education process, therefore, they can get the obedience and worship of the educated ones. However, the network gives people equal access to information, the access of the educated information is no longer dependent on the teachings of the educators, so the educated ones begin to selectively accept the information instilled by the educators and dare to question the content of the education. It can be seen that the ideological and political education under the condition of the network, the knowledge update and education methods of the educators have been put forward new requirements.

The Outstanding of Moral Quality Problems. At present, the channel of college students to understand the information through the network become wider, more contact, the students receive and disseminate a variety of different cultural forms in an absolutely free environment, good buckwheat information in the mind produce more intense conflict, causing the mind to swing. Internet origin where the western countries output network technology, at the same time, must hype western ideas, morals and values, if the students can not get the advanced ideological and moral guidance in a long-term on the Internet, they must inevitably lose the fine traditional morality. In the university campus, the outstanding performance of good moral quality is the performance of college students academic misconduct rampant. For example, when preparing a thesis, students pilfer the 
research results of others through the network, or deal with the businessmen who provide the paper writing service in the network. The network provides some convenience for these students with the academic misconduct so that earnestly quality of the students that they can learn and study hard has been negatively affected, but also shaken the formation of the concept of integrity of students, worthy of the great attention for ideological and political education in colleges.

\section{The Countermeasures of College Ideological and Political Education}

The Design of Top Management, To Increase the Input of Funds. In order to really do a good job of network ideological and political education work, so that it can play the greatest role, first of all, we should begin from the school's top management, to recognize the necessity and significance of network education and ideological education. The top design comprehensively planning the school network ideological and political education work. Give the tilt and support for the computer equipment, network construction, the rational allocation of teachers and funding and other aspects, we also need to strengthen publicity within the school, promote the formation of a good atmosphere where everyone are involved and make a response.

Strengthening the construction of network ideological and political teachers. On the one hand, to strengthen the comprehensive quality of workers who are involved in the ideological and political education, to establish the talent team who are both familiar with network and hold abundant ideological and political work experience; on the other hand, strengthening the communication between all aspects of educators, to set up network ideological and political education team approach, realize the complementary of advantages and a clear division of labor to carry out the work.

Change the Education Method. Educators should take full advantage of the interactive role of the network, and actively promote interactive teaching, in addition to classroom teaching, through the network, they can actively participate in student online learning and exchange, such as sharing the quality teaching video with students, setting the theme to organize students to participate the discussion, using principles of ideological and political science to analyze social phenomena, etc. Using the osmotic teaching methods, they should apply the way that students love to subtle adaptation of their ideas, so that their political accomplishment and ideological cultivation continues to be improved. First of, they should arouse the resonance of students, and then solve the problem based on the objective analysis.

Pay Attention to the Application of Mobile Internet in Network Ideological and Political Education. We should fully understand another development trend of the internet revolution, that is, the rapid development of mobile Internet. Notebook computers, handheld computers, especially mobile phone network business have become the new darling of college students. Faced with new network carrier, college network ideological and political education should also be urgent and forward-looking. For now, the widely used mobile phone WeChat, A variety of mobile phone App development and operation, all of that have provided a new opportunity for the ideological and political education in colleges, such as the establishment of public education platform of the network ideological and political education, making the ideological and political education access to life environment of each student, developing mobile phone network ideological and political application software, pushing a variety of student-friendly services, to implement the slogan of serving students really.

\section{Conclusion}

Network education is different from the traditional classroom teaching model, with technical, normative, freedom, broad and other characteristics. Making the combination of the modernly new technology with ideological and political education, will produce great significance like milestone on the development of college students ideological and political education. The target of developing ideological and political education in colleges is promoting the construction of ideological and political education, cultivating excellent college students, creating a new situation of educational 
atmosphere, innovating the brand of school education, and finally realizing the educational system requirements. In the field of network environment where this opportunity and challenge coexist together, we need to take a positive development strategy to enhance the work quality of the network ideological and political education, to guide students to use the network rationally and legally, to enhance communication between teachers and students and promote the campus culture, So as to help the development and innovation of network ideological and political education in colleges.

\section{References}

[1] D Lu, Ideological and Political Education in Colleges:Embarrassment and Countermeasure[J]. Human Molecular Genetics, 2008, 17(19):2997-3009(13).

[2] S.S Shang On Ideological and Political Education for College Students in Internet Situation[J]. Journal of Hubei Normal University, 2004.

[3] H Li Ideological and Political Education Based on Daily Life[J]. Journal of Shandong Teachers University, 2004.

[4] X.J Zhang, Research and Countermeasures of Students' Ideological and Political Education in Higher Vocational Colleges[J]. Journal of Liaoning Higher Vocational, 2013, 18(6):619-629.

[5] B. Zhao, The Innovation of the Ideological and Political Education in Colleges and Universities on the Background of Economic Globalization[J]. Journal of Jilin Teachers Institute of Engineering \& Technology, 2009, 64(6):413-425.

[6] D.L Wang, "Construct of the Content System of Ideological and Political Education in Human Concern." Teaching \& Research (2005).

[7] H.W Wei,YN Zhang, Analysis on the Diversification and Training of the Master of Ideological and Political Education[J]. Education Modernization, 2015, 29(2):879-887.

[8] H Shao, Analysis on Student's Rebellious Mentality in the Ideological and Political Education at University[J]. Journal of Ankang University, 2008, 73(6):1037-1047.

[9] L.S Chen, A Survey of Research on Theories of Ideological and Political Education in the World Today[J]. Teaching \& Research, 2000.

[10] Y Liu, The Integration of Ideological and Political Education with Mental Health Education among College Students[J]. Journal of Yunyang Teachers College, 2006, 108(3):376-384.

[11]X.N Zhu, Wang Y W. Inspirations from Ideological and Political Education in Foreign Countries[J]. Journal of Chongqing University of Post \& Telecommunications, 2004.

[12]X.N Zhu, YW Wang, Inspirations from Ideological and Political Education in Foreign Countries[J]. Journal of Chongqing University of Post \& Telecommunications, 2004. 